\title{
Lumen
}

Selected Proceedings from the Canadian Society for Eighteenth-Century Studies

\section{'The Various Modes of Nature's Least Admirable Workes': or, The Collected Dunciad The Various Modes of Nature's Least Admirable Workes': or, The Collected Dunciad}

\section{Darryl P. Domingo}

Volume 23, 2004

URI : https://id.erudit.org/iderudit/1012188ar

DOI : https://doi.org/10.7202/1012188ar

Aller au sommaire du numéro

Éditeur(s)

Canadian Society for Eighteenth-Century Studies / Société canadienne d'étude du dix-huitième siècle

ISSN

1209-3696 (imprimé)

1927-8284 (numérique)

Découvrir la revue

Citer cet article

Domingo, D. P. (2004). 'The Various Modes of Nature's Least Admirable Workes': or, The Collected Dunciad The Various Modes of Nature's Least Admirable Workes': or, The Collected Dunciad. Lumen, 23, 91-114.

https://doi.org/10.7202/1012188ar

Copyright (c) Canadian Society for Eighteenth-Century Studies / Sociéte canadienne d'étude du dix-huitième siècle, 2004
Ce document est protégé par la loi sur le droit d'auteur. L'utilisation des services d'Érudit (y compris la reproduction) est assujettie à sa politique d'utilisation que vous pouvez consulter en ligne.

https://apropos.erudit.org/fr/usagers/politique-dutilisation/ 


\section{4. 'The Various Modes of Nature's Least Admirable Workes': or, The Collected Dunciad}

By their choice Collections may appear,

Of what is rare in land in sea in air;

Whilst they [as Homer's Iliad in a nut]

A world of wonders in one closet shut

(Inscription to Tradescant Family Tomb).

According to the Musaeum Tradescantianum (1656), the vast collection of the distinguished Tradescant family included such curious specimens as 'The tayle of a Catt fish,' 'Severall sorts of Insects,' a 'beak eleven inches long,' and an assortment of 'Wolfes teeth;' a variety of 'Fossilia,' a sample of 'Old Fustick,' 'Petrified things,' and 'A bundle of Tobacco;' 'Chirurgeons Instruments,' 'A Turkish Toothbrush,' 'A little wheel turned in Amber,' and 'Flea chains of silver and gold;' along with 'A hat-band made of the sting-ray, ' Halfe a Hasle-nut with 70 pieces of householdestuffe in it,' an assemblage of 'Splene-stones,' and, last of the least, 'Divers Figures cut on Shells.' ${ }^{1}$ According to 'A Letter to the Publisher,' Alexander Pope's Dunciad may be seen to house a similar collection of curiosities - a miscellany of trifling treasures and recondite rarities of which 'scarce one is known... by sight' (The Dunciad, p. 14). ${ }^{2}$ Certainly, the poem is well-stocked with the bits and pieces of material culture that might ornament the cabinet of a virtuoso collector: the verse is replete with

1 Prudence Leith-Ross, 'Appendix III: Musaeum Tradescantianum,' in The John Tradescants: Gardeners to the Rose and Lily Queen (London: Peter Owen Publishers, 1984), p. 227-93.

2 Alexander Pope, The Dunciad, The Twickenham Edition of the Poems of Alexander Pope, ed. James Sutherland, $3^{\text {rd }}$ ed. (London: Methuen, 1963), 5: p. 14. Further references to The Dunciad will be parenthetically cited by book and line number from this edition. References drawn from the 1729 Dunciad Variorum will be labeled: [A], while references drawn from the 1743 Dunciad in Four Books will be labeled: [B]. 
crapes, garters, and 'shaggy tapestries,' with coins, medals, and parchment scraps, and with the butterflies, bird's nests, fungi, and flowers. It is composed of precisely that which Gregory Columb has defined as the quintessential matter of the mock-heroic work: 'a messy, undifferentiated mass of particulars' along with a 'myriad of details. ${ }^{3}$ But The Dunciad is also stocked, more curiously, with a collection of human trivia. While Pope clearly discovers 'Congenial matter in the Cocklekind' ([B] 4.448), his satiric purpose is to uncover noxious matter of the duncical-kind; and to this end The Dunciad parodies what Barbara Benedict has called 'that curious habit' - collecting. ${ }^{4}$ The poem, with its enormous apparatus, compiles, classifies, and exhibits an obscure order of specimens designated dunce; and as it fills its shelves with such unknown matter as Mears, Roper, and Breval, and stuffs its drawers with such forgotten relics as Durgen, The Flying Post, and Thule, The Dunciad effectively poeticizes the cabinet of curiosities.

A number of scholars have drawn attention to the ways in which the poet and his poem engage early modern curiosity and the culture of collecting. Benedict, for instance, has described The Dunciad as a 'baroque collection' crowded with 'abortions, excrement-strewn villains, and demons.' Dennis Todd has examined Pope's attack on the virtuosi, whose mindless accumulation of curiosities threatened the idleness of the imagination.' Joseph M. Levine has analyzed the career of one such virtuoso, the distinguished physician, geologist, and antiquarian, Dr. John Woodward, in order to explain both how he became a perennial butt of Scriblerian satire, and why he rose above it. And Maynard Mack has suggested Pope's own implication in his satire by tracing the evolution of his Twickenham Grotto, which contained, among other things, 'many small Dice of Mundic,' 'several Humming Birds and their Nests,' two kinds of 'yellow flaky Copper,' and 'various sorts of Stones thrown promiscuously together. ${ }^{5}$

3 Gregory Columb, Designs on Truth: The Poetics of the Augustan Mock-Epic (Pennsylvania: The Pennsylvania State University Press, 1992), p. xii-xiii.

4 Barbara Benedict, "The "Curious Attitude" in Eighteenth-Century Britain: Observing and Owning,' Eighteenth-Century Life 14 (November 1990): p. 59.

5 Barbara Benedict, Curiosity: A Cultural History of Early Modern Inquiry (Chicago: The University of Chicago Press, 2001), p. 91. Dennis Todd, Imagining Monsters: Miscreations of the Self in Eighteenth-Century England (Chicago: University of Chicago Press, 1995), p. 208. Joseph M. Levine, Dr. Woodward's Shield:History, Science, and Satire in Augustan England (Ithaca: Cornell University Press, 1991), especially p. 114-29 and p. 238-52. Maynard Mack, The Garden and the City: Retirement and Politics in the Later 
Provocative though these studies may be, they tend to focus on the matter of The Dunciad at the expense of the manner; that is, each discussion considers the material and human objects of collection, whether the 'canker' $\mathrm{d}$ ' coins of competing numismatists or the historical identities of Annius and Mummius, while neglecting the manner in which these objects are satirically presented. A partial exception is Pat Rogers' essay, 'Pope and the Antiquarians,' which tantalizingly argues that The Dunciad 'textualizes the concerns of virtuosi,' and thereby parodies the excesses of the 'silent race.' He points to Pope's codification of the activities of dulness in 'orderly lines and neatly tagged footnotes,' and goes so far to suggest that 'the entire Dunciad has become a sort of cabinet of curiosities. ${ }^{6}$ Since this suggestion, however, is tangential to Rogers' discussion of Pope's complicity in antiquarian pursuit, he unfortunately leaves the duncical cabinet closed. In this paper, I would like to open Pope's cabinet by arguing that the collector's habit of compilation, classification, and exhibition is the structural principle behind The Dunciad - a structural principle, moreover, which allows Pope to contain his dunces both figuratively and literally. ${ }^{7}$ I will ignore the poem's many allusions to antiquarians, lepidopterists, curiosos, bibliophiles, and other enthusiasts in 'things,' since my concern is form not content - the means, not the ends of Pope's satire. The substantial historical and scientific achievements of such dunces as Woodward, Thomas Hearne, and William Stukeley will, therefore, be considered secondary to their characteristic methods of collecting what they deemed the various modes of Natures admirable workes. ${ }^{8}$ In The Dunciad, Pope collects what he deems 'Nature's least admirable workes;' the virtuosic satirist gathers together the seemingly irrelevant action of insignificant characters who occupy themselves with inconsequential things. The Dunciad thus becomes a burlesque embodiment of the collector's habit, as well as an apropos

Poetry of Pope, 1731-1743 (Toronto: University of Toronto Press, 1969), especially p. 3-115 and Appendix C, p. 259-62.

6 Pat Rogers, 'Pope and the Antiquarians,' Essays on Pope, ed. Pat Rogers (New York: Cambridge University Press, 1993), p. 253.

7 See Harold Weber, 'The "Garbage Heap" of Memory: At Play in Pope's Archives of Dulness,' Eighteenth-Century Studies 33:1 (1999), p. 1-19. Weber argues, along similar lines, that Pope exploits the satiric potential of the archive to make the present available to the future and to establish as 'cultural memory' the singular perspective of the archivist.

8 The phrase is taken from 'To the Ingenious Reader' in The Musaeum Tradescantianum. Cited in Leith-Ross, p. 231. 
elaboration of the Scriblerian mandate: to collect the complete works of the unlearned. ${ }^{9}$ As Martinus Scriblerus himself puts it: 'I doubt not but an active Catcher of Butterflies...[and] an industrious Collector of Shells...might severally excel in their respective parts of the Bathos. ${ }^{10}$

\section{That 'Curious Habit' - Collecting}

And severally they did excel. In what Pope believed to be the bathetic climate of late seventeenth- and early eighteenth-century England, curious collecting verily became habitual. Numbers of enthusiasts were seized by the virtuoso impulse which encouraged them to assemble 'Rarities for Rareness-sake. ${ }^{11}$ The true empirical impulse, as delineated by Bacon, had been distorted by those whose collection of 'nature in course,' 'nature altered or wrought,' and, most often, the 'Heteroclites or Irregulars of nature' was an end in itself, rather than a preliminary step to the 'inventory' of nature. ${ }^{12}$ From the humanist perspective, such collectors had confused the ornamental motivations of collection with the instru-

9 For a discussion of the Scriblerian attitude towards collectors and collecting see Charles Kirby-Miller's thorough introduction to The Memoirs of Martinus Scriblerus, ed. Charles Kirby-Miller (New York: Oxford University Press, 1988), especially p. 68-77 and p. 203-6, as well as Rogers, 'Pope and the Antiquarians,' p. 240-60 and Levine, Dr. Woodward's Shield, especially p. 238-52.

10 Alexander Pope, Peri Bathous: Or, Martinus Scriblerus, His Treatise on the Art of Sinking in Poetry, The Prose Works of Alexander Pope: Volume II, ed. Rosemary Cowler (Hamden: Archon Books, 1986), sec. 6: p. 196. All subsequent references are to section and page.

11 See Walter E. Houghton Jr., 'The English Virtuoso in the Seventeenth Century,' Journal of the History of Ideas 3 (1942): p. 51-73 and 4 (1942): p. 190-219. Houghton's study remains the standard historical survey of the English virtuoso. For more recent discussions of early modern English collecting see: Richard D. Altick, 'From Cabinets to Museums I, 1600-1750,' The Shows of London (Cambridge: Belknap Press of Harvard University, 1978), p. 5-21; Arthur MacGregor, 'The Cabinet of Curiosities in Seventeenth-Century Britain,' The Origins of Museums: The Cabinet of Curiosities in Sixteenth- and Seventeenth-Century Europe, eds. Oliver Impey and Arthur MacGregor (Oxford: Clarendon Press, 1985), p. 147-58; Levine, Dr. Woodward's Shield, especially p. 93-113; and Benedict, 'The "Curious" Attitude in Eighteenth-Century Britain,' p. 59-98. For contemporary early modern commentary on collecting see: The Collector's Voice: Critical Readings in the Practice of Collecting, Volume II: Early Voices, eds. Susan Pearce and Ken Arnold (Burlington: Ashgate Publishing Company, 2000). For an interesting 'reconstruction' of the eighteenth-century cabinet, see Enlightenment: Discovering the World in the Eighteenth Century, ed. Kim Sloan (London: British Museum, 2003).

12 Francis Bacon, The Advancement of Learning, The Major Works, ed. Brian Vickers (New York: Oxford University Press, 1996), p. 176. 
mental, and had divorced the act of assemblage from the more important process of interpretation. Although these private collections were eventually to form the basis of public museums, the Augustan satirists could see only quantity devoid of quality. As 'professional' and amateur alike crammed their cabinets with the disparate artifacts of material existence, the meaningful context of these artifacts was often swamped by their sheer miscellaneity. Pope's pell-mell description of the virtuosi with their curiosa is, therefore, not so hyperbolical:

Then thick as Locusts, black'ning all the ground, A tribe, with weeds and shells fantastic crown'd, Each with some wond'rous gift approach'd the Pow'r, A Nest, a Toad, a Fungus, or a Flow'r. ([B] 4.397-400.)

The curious eye of the curious collector was naturally drawn to the novel, the minute, or the obscure, not because they possessed any tangible value, but rather because possession of the novel, the minute, or the obscure was seen as intrinsically valuable. The 'Curious Man,' according to Samuel Butler, 'Values things not by their Use or Worth, but Scarcity.' Objects within the cabinet of curiosities are divested of all practical notions of purpose and function, and assume instead an exclusively subjective status. 'That which other Men neglect,' continues Butler, '[the Curioso] believes they oversee, and [he] stores up Trifles as rare Discoveries, at least of his own Wit and Sagacity. ${ }^{13}$ And therefore, to borrow a phrase from John Clark, both the curious man and his curious collection are 'withdrawn into singularity. ${ }^{14}$ Sandals made of twigs, the testicles of a beaver, Indian figs, a set of chess-men in a peppercorn - all these become valuable to the degree that they are equivocal to everyone but the collector himself. The standard of evaluation is necessarily idiosyncratic. As such, the most trifling of collections may appear as true, as good, as profound, from the collector's point of view, as a more obviously meaningful one.

Pope's trifling collection is no less singular than Tradescant's twigs and figs. The company of dunces who ornament The Dunciad are presented as objectively inaccessible. The 'Preface' of 1728 acknowledges: 'I

13 Samuel Butler, Characters, ed. Charles W. Daves (Cleveland: Press of Case Western Reserve, 1970), p. 104-6.

14 John R. Clark, Form and Frenzy in Swift's 'Tale of a Tub' (Ithaca: Cornell University Press, 1970), p. 19. 
would not have the reader too much troubled or anxious, if he cannot decypher them; since when he shall have found them out, he will probably know no more of the Persons than before' (p. 206). In themselves, that is to say historically speaking, Ralph, Concanen, and Welsted are, perhaps, inconsiderable; but once they are heaped into the capacious compendium of The Dunciad, their value is no longer so slight. They become Pope's choice specimens, his rarities, his duncical treasures. The point is not that Pope's judgements are accurate or even justifiable, but that in the context of the collector's habit they need not be. The cabinet of curiosities stands as a metaphor for the relation between the collector and his world. The assembled artifacts produce and project a kind of 'personal microcosm' that elaborates the ideals of the collector and reconciles these ideals to the social and material realities of his environment. Against the presumed threat of 'Chaos and eternal Night,' challenged by a 'deluge of authors' who cover the land, confronted with the removal of Dulness 'from the city to the polite world,' the collector's habit becomes a virtuosic vehicle for normative satire. Pope's creative act of compilation, classification, and exhibition essentially grants him ownership over the dunces, thus giving him license to treat them in whatever way he wishes. As a collector sorting through his collection, Pope may disregard Richard Bentley's genius as a classical scholar, Eliza Haywood's story-telling abilities, and John Dunton's noteworthy efforts to popularize the 'new science.' In the cabinet of dulness, Bentley is simply a 'tempestuous' pedant ([B] 4.201), Haywood a 'profligate,' 'shameless,' and 'libellous' author ([A] 2.149n), and Dunton 'a broken Bookseller and abusive scribler' ([A] 2.136n). Pope takes inventory of what he perceives as Nature's least admirable works, and in so doing pointedly imposes his own particular image of the decay of English culture. Collecting, according to Susan Pearce, 'is an important way in which we can assert our impulses towards dominance and control. ${ }^{15}$

15 Susan M. Pearce, On Collecting: An Investigation Into Collecting in the European Tradition (London: Routledge, 1995), p. 195. In recent years, much scholarship has been directed towards the ideological implications of collecting. See, for instance: Amy Boesky, '“Outlandish-Fruits": Commissioning Nature for the Museum of Man,' English Literary History 58 (1991): p. 305-30; Sean Hides, 'The Genealogy of Material Culture and Cultural Identity,' Experiencing Material Culture in the Western World, ed. Susan Pearce (London: Leicester University Press, 1997); The Politics of Display: Museums, Science, Culture, ed. Sharon Macdonald (New York: Routledge, 1998); Anthony Alan Shelton, 'Cabinets of Transgression: Renaissance Collections and the Incorporation of the New World,' The Cultures of Collecting, eds. John Elsner and Roger Cardinal (London: Reaktion Books, 1994), p. 177-203; and, especially, Susan Stewart, On 
Within the confines of an ideological cabinet, representations of transgressive cultures or sub-cultures - for instance, the 'Grub-street race' can be literally contained by way of the figurative containment of the collection. The taxonomic and spatial bounds of the one become the psychological and social bonds of the other; and it is this capacity to bind, to contain, to confine that Pope exploits in The Dunciad. It is thus no wonder that he writes to Swift, shortly prior to publication: 'This Poem will rid me of those insects. ${ }^{16}$

\section{Curious Compilation}

Insects, after all, were a ubiquitous component of the curiosity cabinet; and for Pope to characterize his duncical opponents as such is to reify them into mere matter, to transform them into collectibles. Ozell might be a snail pressed under glass, Prynne a beetle housed in a wooden case, and Oldmixon a fly pinned to a pasteboard. The study of insects and the scrutiny of duncehood become synonymous. Unlike Shadwell's Sir Nicholas Gimcrack, Pope studies insects not because 'Tis below a Virtuoso to trouble himself with Men and Manners,' but because 'Men and Manners' have been reduced to a branch of entomology. ${ }^{17}$ In The Dunciad the contentious subject becomes, quite literally, the collected object. The dunces are 'clapp'd in as they rose,' and, depending on the collector's individual prowess and personal caprice, are shuffled about in their Niches' and shifted from slot to duncical slot (p. 206). It is the collective integrity of duncehood, rather than the integrity of particular specimens of duncehood which is at stake. In the words of Jean Baudrillard, 'all objects in a collection become equivalent, thanks to the process of passionate abstraction we call possession. ${ }^{18}$ The generic function of each object is simply to be collected. One dunce differs little from another insofar as each represents so much raw material for Pope's cabinet. And,

Longing: Narratives of the Miniature, the Gigantic, the Souvenir, the Collection (Baltimore: The John Hopkins University Press, 1984), p. 132-70.

16 Pope to Swift, 23 March 1728, The Correspondence of Alexander Pope, ed. George Sherburn, 4 vols. (Oxford: Clarendon Press, 1956), 2: p. 481. Further correspondence will be cited from this edition.

17 Thomas Shadwell, The Virtuoso, eds. Marjorie Hope Nicholson and David Stuart Rhodes (Lincoln: University of Nebraska Press, 1966), act 3, sc. iii, lines 88-89.

18 Jean Baudrillard, 'The System of Collecting,' trans. Roger Cardinal, The Cultures of Collecting, eds. John Elsner and Roger Cardinal (London: Reaktion Books, 1994), p. 8. 
to rephrase the original 'Preface,' whoever will consider the unity of this cabinet, will be sensible, that the collection was not made for these authors, but these authors for the collection (p. 205). Pope did not design The Dunciad in order to house his curiosities but rather accumulated curiosities with which to stock his Dunciad. The poem is thus both a collection and the product of collection, both a satire on dulness and a cumulative embodiment of this dulness.

Like a responsible virtuoso, Pope dug deep and laboured long in order to compile suitable contents for his cabinet. He sedulously sought out all those who, in his estimation, followed the commands of the 'cloud-compelling Goddess': to 'be proud, be selfish, and be dull' ([B] 4.582). Pope first exercised the collector's habit in Peri Bathous (1728), a mock-treatise in which he assembles, sets out, and scrupulously sorts the many species of the profound, as exemplified by such authors as Richard Blackmore, Ambrose Phillips and John Dennis. 'I propose to collect,' writes Scriblerus, 'the scatter'd Rules of our Art into regular Institutes, from the example and practice of the deep Genius's of our nation. ${ }^{19}$ The treatise is composed of citations drawn directly from contemporary sources. As such, the accumulated writers of the bathos are made ironically to incriminate themselves by serving as inadvertent authorities for 'the art of sinking in poetry.' Blackmore is found to excel in 'The Jargon': 'Thy Head shall rise, tho' buried in the Dust, / And 'midst the Clouds his glittering Turrets thrust.' Philips is distinguished by his capacity for 'Inanity': 'Ah silly I, more silly than my Sheep, / (Which on the flow'ry Plain I once did keep).' And Dennis is lauded for his 'Finical' style: 'Oaks whose extended arms the winds defy, / The tempest sees their strength, and sighs, and passes by. ${ }^{20}$ It was a characteristic Scriblerian technique to punish 'wicked Scriblers' out of their own mouths, and to this end Pope and his associates compiled and maintained bibliographical records of their opponents. If Scriblerian satire figuratively collects the dunces, it is only because Scriblerian libraries literally collected them.

19 Peri Bathous, 1: p. 187. In fact, Scriblerus goes so far as to recommend that the 'Rules of our Art' be organized and stored within a 'Rhetorical Chest of Drawers, consisting of three Stories, the highest for the Deliberative, the middle for the Demonstrative, and the lowest for the Judicial. These shall be divided into Loci or Places, being repositories for Matter and Argument in the several kinds of oration or writing; and every Drawer shall again be subdivided into Cells, resembling those of Cabinets for Rarities.' (13: p. 225) Perhaps nowhere else in the Scriblerian canon, is the relationship between duncical collecting and curious collecting made so overt.

20 Peri Bathous, 10: p. 209, 11: p. 215, 12: p. 222. 
One can imagine the curious compiler at work: 'Studious he sate, with all his books around, / Sinking from thought to thought, a vast profound!' ([A] 1.111-12.) A survey of 'Pope's Books' reveals that preserved alongside the sublime works of Homer and Virgil, Shakespeare and Jonson, Milton and Dryden are the works of such less than lofty authors as John Roberts, Aaron Hill, and Edmund Curll. ${ }^{21}$ A 1734 letter from Pope to the publisher Jacob Tonson, illustrates the poet's will not only to amass his duncical antagonists, but to bind them as well:

I desire...you'l cause the Paquet I send, to be bound together, as many in a Volume as are tyed together. Let the Octavo be made to match in colour \& Size this which is already bound, \& Letter it LIBELS, ON POPE \&c Vol. 2d. Pray Bind the duodecimos also in another vol. the same colour, Letterd CURL \& COMPANY...And Bind the Gulliveriana, \& letter it thus, LIBELS ON SWIFT \& POPE. $^{22}$

These meticulous instructions resulted in a four-volume set which contained twenty-four libels relating to Pope and the Scriblerians; and out of these libels, Pope drew much of the material for The Dunciad. Just as the poet's own library was adorned by the ephemeral productions of Duckett, Smedley, and Roper, so too his Dunciad is consciously presented as a treasure-house for trivia: a collection of 'all such reading as

21 See Maynard Mack, 'Pope's Books: A Bibliographical Survey with a Finding List,' English Literature in the Age of Disguise, ed. Maximillian E. Novak (Berkeley: University of California Press, 1977), p. 209-305. See also Joseph V. Guerinot, Pamphlet Attacks on Alexander Pope, 1711-1744 (New York: New York University Press, 1969).

22 Pope to Tonson, n.d., 1734 (3: p. 399) For a complete catalogue of the contents of these four volumes, see Pope's 'Library of Dunces': or, Appendix. Interestingly, The Dunciad Variorum compiles its own catalogue of duncical offenders. 'Appendix $\mathrm{II}^{\prime}$ offers 'A list of books, papers, and verses, in which our author was abused, printed before the publication of The Dunciad: with the true names of the authors', as well as a list of libels published 'After The Dunciad, 1728'. These lists exemplify the collective monomania of Pope the virtuoso, while functioning to justify the duncical collection of Pope the satirist. By assembling, and incorporating into his Dunciad, for instance, Burnet and Ducket's Homerides (1715), Thomas Cooke's Battle of the Poets, a Heroic Poem (1725), Edumund Curl's Popiad (1728) and a miscellany of derogatory letters from Mist's Weekly Journal, the Flying Post, and the Daily Journal, the virtuosic satirist is able to group his opponents under the general category of dulness. 'What has [The Dunciad] said of them?', queries 'A Letter to the Publisher', 'a very serious truth...that they were dull: and what it had no sooner said, but they themselves were at great pains to procure or even purchase room in the prints, to testify under their hands to the truth of it.' (p. 12) 
was never read' ([A] 1.166). The tellingly titled 'Index of Things (including Authors),' which is affixed to the poem, arranges the whirligig, the birch rod, and the Maypole alongside Besaleel, Gildon, and Bethel in such a way as to invite a comparison between the curiosities of life and the curiosities of literature. The poem, as Pat Rogers suggestively writes, exhibits itself as 'at once a cento of literary fragments and an assemblage of bric-a-brac. ${ }^{23}$ 'Lo,' Pope interjects portentously, it is comprised of such mean matter as

Haywood, Centlivre, Glories of their race!

Lo Horneck's fierce, and Roome's funeral face;

Lo Bond and Foxton, ev'ry nameless name,

All crowd, who foremost shall be damn'd to Fame? ([A] 3.145-52.)

The selection of objects is the most challenging creative task facing the collector. Any criterion for inclusion must provide that artifacts be attractive enough to engage the attention of observers, as well as singular enough to accommodate the collector's monomania. Within the context of curious collecting, the more 'nameless' the name, the more novel the ornament. Insignificance, irrelevance, and inconsequence necessarily become the touchstones of collected dulness. By gathering together such 'dark and dirty' authors as Ridpath, Ogilby, and Johnson, Pope the virtuoso delights the curious with his collection: 'the reader cannot but derive one pleasure from the very Obscurity of the persons it treats of' (p. 8). Moreover, the inclusion of such abstruse specimens as Cooke, Woolston, and Moore-Smythe satisfies Pope the satirist insofar as it allows him to make the dunces his own. William Cleland, under the direction of Pope, observes in his 'Letter to the Publisher': 'The first objection I have heard made to the Poem is, that the persons are too obscure for Satyre.' (p. 14.) While obscurity might be an objection to a satiric poem, it is actually a qualification for a satiric collection. As Benedict explains: 'Collections...celebrate the collector's power to subdue the meanings of objects into his own meaning, to define value. ${ }^{24}$ If the collector decontextualizes the collected by the very act of collection, it is also his prerogative to recontextualize collected objects. And thus it

23 Rogers, p. 245.

24 Benedict, p. 75. 
is that Pope's 'Library of Dunces' allows him to acquire 'such a peculiar right over their Names' (p. 202 n. a). Pope not only compiles the 'nameless', but assumes the authority to name the nameless as well.

\section{Curious Classification}

And apparently the nameless required naming. The 'Preface' to the 1728 Dunciad in Three Books claims that 'those Names which are its chief ornaments, die off daily so fast, as must render it too soon unintelligible.' (p. 203.) One might vainly seek, as Cleland ostensibly does, through the 'closets and libraries' of all their acquaintance, without coming to any knowledge of The Dunciad's contents (p. 14). Subjective, singular, and slight, Pope's curiosities necessarily provoke curiosity: like the mid-section of a locust or a cherry-stone holding ten dozen tortoise-shell combs, the dunces are simply too small to be appreciated. Yet the dunces might be enlarged. Nine days after its initial exhibition (18 May 1728), Oxford wrote to Pope that The Dunciad would be greatly improved if published along with notes to elucidate its more trivial references. And in a letter from Swift to Pope, the Dean remarks: 'I am sure it will be a great disadvantage to the poem, that the persons and facts will not be understood, till an explanation comes out, and very full one. ${ }^{, 25}$ When collecting dunces, as in collecting generally, 'the plentitude of taxonomy opens up the space for collectibles to be identified, but at the same time the plentitude of that which is to be collected hastens the need to classify. ${ }^{26}$ In order to give significance to the insignificant, grant relevance to the irrelevant, and generate consequence out of the inconsequential, the curious compiler must then turn curious classifier.

Curiosity collectors of previous generations had gradually recognized this fact. When perplexed by how to organize his father's grand but haphazard collection, John Tradescant the younger determined to 'catalogue' and 'enumerate' the rarities. In the resulting Musaeum Tradescantianum, specimens were initially arranged under the rubrics of 'Natu$\mathrm{ral}^{\prime}$ and 'Artificiall,' and were then further sorted under a variety of

25 The Earl of Oxford to Pope, 27 May 1728 (2: p. 496); Swift to Pope, 16 July 1728 (2: p. 504).

26 John Elsner and Roger Cardinal, 'Introduction' to The Cultures of Collecting, eds. Elsner and Cardinal (London: Reaktion Books, 1994), p. 1-2. 
sub-headings, which made some attempt to define the nature and classify the characteristics of each:

Now for the materialls themselves I reduce them unto two sorts; one Naturall, of which some are more familiarly known \& named amongst us, as divers sorts of Birds, foure-footed Beasts and Fishes....Others lesse familiar... as the shell-Creatures, Insects, Mineralls, Outlandish-Fruits, and the like, which are part of the Materia Medica....The other sort is Artificialls, as Vtensills, Householdstuffe, Habits, Instruments of VVarre used by several Nations, rare curiosities of Art, $\& c{ }^{27}$

The younger Tradescant supplied the rarities with identifiable nomenclature and with historical and scientific context, thereby drawing them out of obscurity and placing them in a rational setting more conducive to examination, comparison, and ready appreciation. The catalogue of curiosities functioned to make the cabinet of curiosities more comprehensible, and thus it became a vital means for arriving at the desired interpretation. Once inserted into the systematic order of the Musaeum Tradescantianum, the mid-section of a locust and a cherrystone holding ten dozen tortoise-shell combs became objects of curiosity, as well as potential knowledge. The Tradescant catalogue, in turn, became a model for classificatory pursuits to follow. English collectors were no longer content simply to accumulate curiosities; rather, responsible virtuosi were obliged to describe and define their accumulations as well. 'By 1700,' explains Pearce, 'the gaze [of the collector]...was concentrated upon measurement and distinction, and upon notions of classification as the explanatory paradigm. ${ }^{28}$

27 'To the Ingenious Reader' in The Musaeum Tradescantianum. Cited in Leith-Ross, p. 231.

28 Pearce, p. 123. Dr. John Woodward emphatically argued that collecting was futile without classification. He writes: 'Censure would be his Due, who should be perpetually heaping up of Natural Collections, without Design of Building a Structure of Philosophy out of them, or advancing some Propositions that might turn to the Benefit and Advantage of the World. This is in reality the true and only proper End of Collections... and they are of no manner of Use of Value without it' (Cited in Pearce, p. 118). In The Dunciad, especially Book 4, Pope follows Woodward's advice, only to scathingly satirize the Doctor and other collectors like him. In the extended passage dealing with the mania for collection ([B] 4.337-458), Pope builds an inverted 'Structure of Philosophy' by classifying his various antiquarians and virtuosi as false, foolish, stinking, and, in general, trifling. His satiric treatment of collectors and collecting thus turns 'to the Benefit and Advantage of the World', insofar as it 
Accordingly, by 1729, Pope's gaze was concentrated upon duncical classification. ${ }^{29}$ To manage and make known the curious contents of his poetic cabinet, Pope published the fulsomely annotated and garrulously be-prosed Dunciad Variorum. Following the advice of his literary associates and the example of his virtuoso predecessors, this new edition was 'to be printed in all pomp.' As he wrote to Swift as early as June 1728, 'It will be attended with Proeme, Prolegomena, Testimonia Scriptorium, Index, and Notes Variorum. ${ }^{30}$ Appending to the collective poem a collective apparatus, the Variorum assembles the 'keys' and 'articles,' the 'opinions' and 'exercitations,' and the 'various judgements' attributed to a company of commentators, all of whom attempt to 'catalogue' and 'enumerate' the curiosities of dulness. Where the Musaeum Tradescantianum sorted its 'Outlandish-Fruits' and 'Householdstuffe' under general

ostensibly aims to reform folly. The ironic result, then, is that 'Censure' becomes the 'Due' of the Doctor himself.

29 Actually, Pope's first attempt at duncical classification occurs in the Peri Bathous (1728), where he respectively categorizes the writers of the bathos as Swallows, Ostridges, Parrots, Didappers, Porpoises, Frogs, Eels, and Tortoises: 'I shall range these confin' $\mathrm{d}$ and less copious Genius's under proper classes, and (the better to give their pictures to the reader) under the names of Animals of some sort or other; whereby he will be enabled, at the first sight of such as shall daily come forth, to know to what Kind to refer, and with what Authors to compare them.' (6: p. 196)

30 Pope to Swift, 28 June 1728 (2: p. 503). Like the poem itself, the amplified apparatus of The Dunciad Variorum is ubiquitously presented as both a collection and the product of collection. In the first place, the 'Advertisement' explains that 'this Edition' of The Dunciad has been made 'more correct and compleat' through the application of commentary drawn from 'several hands' (p. 8). The Variorum notes which accompany the poem are clearly the result of a cumulative effort: Bentley, Theobald, Dennis, Jacob, Curll, and, among others, the poet himself contribute their particular 'opinions' and 'exercitations', thus producing a collection of commentary upon a collection. The 'Advertisement' further observes that the addition of 'The Imitations of the Ancients' and 'the Parodies and Allusions to the most excellent Moderns' threaten to make the poem 'too much a Cento' (p. 9) - that is, a work composed of the collected fragments of other works. The 'Testimonies of Authors Concerning our Poet and his Works' is likewise a collection of other works. 'Before we present thee with our exercitations on this most delectable Poem', writes Scriblerus, 'we shall here, according to the laudable usage of editors, collect the various judgements of the Learned concerning our Poet....Nor shall we gather only the Testimonies of such eminent Wits, as would of course descend to posterity, and consequently be read without our collection; but we shall likewise with incredible labour seek out for divers others, which, but for this our diligence, could never at the distance of a few months appear to the eye of the most curious.' (p. 23) Ironically, as the 'distance' of a few hundred years has shown, the 'diligence' of Pope has given his dunces a curious posterity. 
headings and particular sub-headings, the Dunciad Variorum organizes its dunces into general vocational groups with particular vocational habits. The Dunciados Periocha, for instance, categorizes the participants of the Second Book's 'publick Games and sports' according to their respective bathetic talents:

Hither flock the Poets and Criticks, attended (as is but just) with their Patrons and Book-sellers. The Goddess is first pleased for her disport to propose games to the latter, and setteth up the phantom of a poet which the booksellers contend to overtake....Afterwards the exercises for the Poets, of Tickling, Vociferating, Diving: the first holds forth the arts and practices of Dedicators, the second of Disputants and fustian poets, the third of profound, dark, and dirty authors. Lastly, for the Criticks, the Goddess proposes (with great propriety) an exercise not of their parts but their patience; in hearing the works of two voluminous authors, one in verse and the other in prose, deliberately read, without sleeping.... ${ }^{31}$ (p. 55.)

Here the Variorum classification delineates, as it were, the 'Naturall' or 'Artificiall' character of poets and critics, and correspondingly assigns a kind of composite meaning to common species of dulness. Elsewhere, the Variorum assigns individual meaning to more singular specimens. Ralph is defined as a proud dunce: 'this low writer constantly attended his own works with Panegyricks in the Journals' ([A] 3.159n). Concanen is characterized as a duncical ingrate: 'an Irishman, an anonymous slanderer, and publisher of other men's slanders, particularly on Dr. Swift to whom he had obligations' ([A] 2.130n). And 'shameless Curl' is identified as a lewd and licentious dunce - as both a 'prostitute' book-seller, and a book-seller who coincidentally consorts with prostitutes. The 'exalted' arc of his urine during the pissing contest prompts Scriblerus to expound extravagantly upon a 'burning passage':

In a manuscript Dunciad...I have found another reading of these lines, thus, And lifts his urn thro' half the heav'ns to flow;

31 'Martinus Scriblerus of the Poem' offers a kind of meta-commentary on the classification of the Pan-bathetic Games: 'Each of the Games relateth to some or other vile class of writers. The first concerneth the Plagiary, to whom he giveth the name of More; the second the libellous Novelist, whom he styleth Eliza; the third the flattering Dedicator; the fourth the bawling Critick or noisy Poet; the fifth the dark and dirty Party-writer; and so of the rest, assigning to each some proper name or other, such as he cou'd find' (p. 52). 
His rapid waters in their passage glow.

This I cannot but think the right: For first, tho' the difference between burn and glow may seem not very material to others, to me I confess the latter has an elegance, a Jenesçay quoy, which is much easier to be conceiv'd than explain'd. Secondly, every reader of our Poet must have observ'd how frequently he uses this word glow in other parts of his works. ... ([A] 2.175n)

Scriblerus proceeds to catalogue seven instances of the word 'glow' in Pope's Homer alone, simply for the sake of proving 'his fondness for this beautiful word.' He ironically acknowledges that though 'burn' more accurately conveys an idea of 'what was said to be Mr. Curl's condition at the time,' Pope had more 'humanity' than to insult a man for a misfortune resulting 'from an unhappy communication with another.' If such a quibble over diction seems to be an inordinately pedantic way to classify Curll as incontinent, it is justified insofar as pedantry itself is akin to the collector's habit. Both the pedant and the curious collector are involved in the accumulation of ostentatious trivia, and both, moreover, are inclined to grow 'too luxuriant in examples.' 32 'The Pedant,' explains Butler, 'collects old Sayings and Ends of Verses, as Antiquaries do old

32 The copious pedantry of The Dunciad Variorum is, of course, parodic. For a discussion of the way in which Pope adopts and adapts the excesses of so-called 'verbal criticism' see: Joseph M. Levine, The Battle of the Books: History and Literature in the Augustan Age (Ithaca: Cornell University Press, 1991), especially p. 218-44; and James McLaverty, 'The Mode of Existence of Literary Works of Art: The Case of the Dunciad Variorum', Studies in Bibliography 37 (1984): p. 82-105. For an analysis of Pope's ironic use of objective annotation see: Peter W. Cosgrove, 'Undermining the Text: Edward Gibbon, Alexander Pope, and the Anti-Authenticating Footnote,' Annotation and its Texts, ed. Stephen A. Barney (New York: Oxford University Press, 1991), p. 130-151; and Anthony Grafton, The Footnote: A Curious History (Cambridge: Harvard University Press, 1997), especially p. 94-121. And, for a study of Pope's textualization of print culture see: William Kinsley, 'The Dunciad as Mock-Book,' Pope: Recent Essays by Several Hands, eds. Maynard Mack and James A. Winn (Hamden: Archon Books, 1980), p. 707-28; J. Paul Hunter, 'From Typology to Type: Agents of Change in Eighteenth-Century English Texts,' Cultural Artifacts and the Production of Meaning: The Page, the Image, and the Body, eds. Margaret J.M. Ezell and Katherine O'Brien O'Keefe (Ann Arbor: University of Michigan Press, 1994), p. 41-69; and James McLaverty, Pope, Print and Meaning (New York: Oxford University Press, 2001). For present purposes, however, the most important pedantic parody in which the Variorum participates is that of contemporary virtuoso praxis. With its extravagant apparatus of prefaces, 'testimonies', royal warrants, and appendices, the volume imitates, according to Pat Rogers, the 'kind of crazed over-documentation which is found among the antiquarian disputes of the age.' (Rogers, 'Pope and the Antiquarians,' p. 253.) 
Coins, and is glad to produce them upon all Occasions. ${ }^{33}$ Therefore, on such as occasions as the exposition of 'the phantom, More,' Scriblerus learnedly evaluates the dunce in terms of his penchant for plagiarism:

It appears from hence that this is not the name of a real person, but fictitious; More from $\mu \omega \rho$ ós, stultus, $\mu \omega \rho_{i} \alpha$, stultitia, to represent the folly of Plagiary. Thus Erasmus: Admonuit me Mori cognomen tibi, quod tam ad Moriae vocabulum accedit quam es ipse a re alienus. Dedication of Moriae Encomium to Sir Tho. More; the Farewell of which may be our Author's to his Plagiary. Vale More! \& Moriam tuam gnaviter defende. Adieu More, and be sure strongly to defend thy own folly. ([A] 2.46n)

In the Dunciad Variorum, the compilation of trivial figures and the compilation of trivial facts converge. While the cabinet of dulness endlessly amasses specimen after duncical specimen, the catalogue of dulness concomitantly piles classification upon classification, ad infinitum. The mockheroic result is that the catalogue swells to a magnitude far greater than the cabinet. The poem is humbled by its Variorum apparatus in the same way that the natural and artificial curiosities of Sir Hans Sloane, eventual founder of the British Museum (1759), were daunted by the thirty-eight folio volumes which attempted to classify them. ${ }^{34}$ But this is only appropriate. Attempts to explain the insignificant, the irrelevant, and the inconsequential must necessarily fill the page with 'contextual information;' and thus, according to Susan Stewart, '[w]riting about the miniature achieves a delirium of description. ${ }^{35}$ Little things require large terms to become large things themselves, and large though these terms might be, they perform the not-so-little task of identifying the contents of the collector's cabinet. If it is the 'most peculiar Talent' of Scriblerus to 'convert every Trifle into a serious thing,' this talent is peculiarly suited to the comprehensive classification of curiosities. ${ }^{36}$ In the pretended absence of estimable proportion, the Variorum provides length, width, and, most bathetically, depth to the dunces. As the 'Advertisement' summarizes: 'Of the Persons it was judged proper to give some account: for since it is only in this monument that they must expect to survive, it seem'd but

33 Butler, p. 187.

34 Edward P. Alexander, Museum Masters: Their Museums and Their Influence (Nashville: The American Association for State and Local History, 1983), p. 29.

35 Stewart, p. 46-47.

36 The Memoirs of Martinus Scriblerus, p. 129. 
humanity to bestow a word or two upon each, just to tell what he was, what he writ, when he liv'd, or when he dy'd' (p. 8).

While the Variorum functions, as it were, to name names and to give a history of each, the nomenclature is partly fictional, and the history is largely subjective. According to Stewart, collecting involves 'the replacement of the narrative of history, with the narrative of the individual subject - that is, the collector himself. ${ }^{\prime 37}$ The experience of the collected and the collector's experience are inseparable. As such, the classification of the collected often becomes the collector's personal chronicle. In, for example, the Catalogue of Dr. John Bargrave's Museum (1676), the curious classifier offers an ostensibly objective description of a fragment of obelisk:

...When I was at Rome, 1646, this obelisk lay broken in 4 or 5 pieces, with the fall of it, in the Circle of the Emperor Caracalla, near St. Sebastian....I took another stone and with it broke off of the butt end of it this piece....Another of these vast stones layeth all along full of hyerogliphics, in that which is now Prince Ludovico's formerly Sallust's garden. And, to see how Rome layeth under its own ashes, one walketh in the streets over one of these famous Egyptian obelisks every day, in a little by passage of a narrow descent that is between Antonina's famous pillar and the Rotunda. I could go directly to it if I were there, but I have forgotten the name of the place.

But the Doctor has forgotten, also, the nature of his artifact. The curious obelisk is lost amidst the curioso's comments upon it. Bargrave continues:

There one day an antiquarian had me down a poor man's cellar and there showed me 4 or 5 yards of one of these pyramids. How far it runneth under ground they know not. It was full of hieroglyphics, and it pitied me to see how the stone was cut and mangled for the convenience to set wine vessels on it. The poor man getteth his rent by showing of it to strangers that are curious - as I confess I always was.... ${ }^{38}$

37 Stewart, p. 156. Stewart further comments that 'each element within the collection is representative and works in combination towards the creation of a new whole that is the context of the collection itself. The spatial whole of the collection supercedes the individual narratives that "lie behind it"' (Stewart, p. 153). As the life and times of the individual dunce is translated into the ink and white space of Pope's cabinet, the reality of a Ralph, a Concanen, or a Curl is replaced by the curiosity of a proud dunce, a duncical ingrate, or a lewd and licentious dunce - all symbolic components of the 'Progress of Dulness'.

38 Bargrave cited in The Collector's Voice, p. 58-59. 
Bargrave's mental curiosity, however, ironically obscures his material curiosity: the character of the collected is subsumed by the character of the collector whose personal anecdotes, peculiar learning, and particular judgements define the artifact as distinctly his own. Like Bargrave's catalogue, Pope's Variorum forgoes objectivity of fact in favour of subjectivity of fancy. Within the duncical cabinet, specimens are sorted and defined according to the singular demands of the collector and his collection, rather than by their actual value. Pope the satirist censures those dunces who direct inordinate attention towards the minutiae of human experience while neglecting the broader significance of these minutiae:

O! would the Sons of Men once think their Eyes

And Reason giv'n them but to study Flies!

See Nature in some partial narrow shape,

And let the Author of the whole escape:

Learn but to trifle or, who must observe,

To wonder at their Maker, not to serve. ([B] 4.453-58.)

Correspondingly, Pope the virtuoso classifies his dunces in such a way as to expose the folly of 'learning but to trifle.' The Variorum polishes Pope's leaden artifacts, in order ironically to make their dulness all the more brilliant. And thus, as Pope writes to Caryll, the notes 'have the art to make trifles agreeable. ${ }^{39}$

\section{Curious Exhibition}

But these trifles are made agreeable, only by making them disagreeable. Pope unflatteringly replaces, or at least displaces reality so as to make his dunces appear more fitting objects for his satire. The more offensive the specimen of dulness, the more effective the corrective to dulness. The Dunciad manipulates history, writes Aubrey Williams, 'by subjecting it to subtle violation'.

The integrity, the actuality, of plain matter of fact is steadily and relentlessly disregarded, and [Pope] proceeds, by artful insinuations, slight but skillful prevarications, misquoting and misrepresenting, to the creation of a revised, a reformed history. ${ }^{40}$

40 Aubrey Williams, Pope's Dunciad: A Study of its Meaning (London: Methuen, 1955), p. 62. 
In The Dunciad fact and fancy generally 'get a jumbled race'. Brown and Mears are classified, for instance, as 'Printers for Tibbald, Mrs. Haywood, or any body' ([A] 3.20n). While the reference to Theobald and Haywood is drawn from the virtuoso's objective knowledge of his artifacts, the addition of 'or any body' shrewdly satirizes indiscriminate publishing. Elsewhere, Pope exploits the objective knowledge of competing collectors. In his classification of Ned Ward he both cites Giles Jacob's Lives of the Poets, and incorporates his own pointed observations:

Edward Ward, a very voluminous Poet in Hudibrastick Verse, but best known by the London Spy, in Prose. He has of late Years kept a publick house in the City (but in a genteel way) and with his wit, humour, and good liquor (Ale) afforded his guests a pleasurable entertainment. ([A] 1.200n)

After Jacob parenthetically defends Ward's 'genteel' behaviour, Pope parenthetically censures him as a mere alehouse keeper and, by implication, a base writer. A subtle alteration thus facilitates character assassination. 'By carefully controlling the context,' explains Williams, the poet can make the name become a name of whatever he chooses. ${ }^{41}$ And often, the name itself becomes the context. In the Preface to the Musaeum Regalis Societatis. Or a Catalogue and Description of the Natural and Artificial Rarities Belonging to the Royal Society... (1681), Nehemiah Grew argues:

the Names of Things should be always taken from something more observably declarative of their Form, or Nature. The doing of which, would much facilitate and Improve the Knowledge of them many ways. For so, every Name were a short Definition. ${ }^{42}$

As a 'Name of Things,' 'Tibbald' might very well be Pope's attempt at 'a short Definition.' Although a footnote explains: 'Lewis Tibbald (as pronounced) or Theobald (as written)...was Author of some forgotten Plays, Translations, and other pieces' ([A] 1.106n), the meaning of this curiosity is perhaps self-evident. The mock spelling of Theobald's name contains within it the motivation for Pope's mockery. The pedantic verbal critic becomes the prime specimen in the original Dunciad because both his works and the nomenclature by which he is specified identify him as a piddler. Pope collapses the distinction between proper and

41 Williams, Pope's Dunciad: A Study of its Meaning, p. 67.

42 Grew cited in The Collector's Voice, p. 95-96. 
common nouns, thereby mounting a 'Tibbald' as the perfected object of dulness. ${ }^{43}$ In this case, Pope transmutes his dunce into a fictional construct and imposes upon it a character he knew it never actually possessed. And in many other cases, Pope wrenches away the character he knew his dunces did possess. Eusden is easily dismissed by a note that invites the curious to 'See Eusden's whole Works (if to be found);' Welsted is diminished to a trifle who 'writ other things which we cannot remember;' and Oldmixon is ridiculed as a person who 'wrote numbers of books which are not come to our knowledge' ([A] 1.71n; 2.293n; 2.199n). As the poem implies, however, these books need not come to our knowledge. If the compilation and classification of curiosities is highly self-conscious, so too is curious exhibition. Once the dunces have been assimilated into the collector's world, the collector may present them in any manner that he chooses. The verity of truths, half-truths, and lies is irrelevant provided that they are the collector's truths, half-truths, and lies. Far from representing an objective world in miniature, the duncical cabinet offers the contents of Pope's mental shelves and drawers. Pope the virtuoso exhibits, for example, a rarity known as Settle, while Pope the satirist follows to classify this rarity singularly:

Settle was...Poet to the City of London. His office was to compose yearly panegyrics upon the Lord Mayors, and Verses to be spoken in the Pageants....Mr. Settle was once a writer in some vogue, particularly with his Party; for he was the author or publisher of many noted Pamphlets in the time of King Charles the second. He answered all of Dryden's political Poems; and being cry'd up on one side, succeeded not a little in his Tragedy of the Empress of Morocco (the first that was ever printed with Cuts). ([A] 1.88n)

From Pope's remarks, the curious may deduce that Settle is a time-server, a partisan, a poetaster, and an insipid playwright. The note offers a kind of marginal paradoxical encomium, insofar as the collector lauds his rarity for precisely that which should depreciate it. Settle is rare, but for

43 For a discussion of Pope's irreverent satiric play with nouns see: Williams, Pope's Dunciad: A Study of its Meaning, especially p. 60-86; Blakey Vermeule, 'Abstraction, Reference, and the Dualism of Pope's "Dunciad",' Modern Philology 96, no. 1 (August 1998): p. 16-41; and, in particular, Pat Rogers, 'The Name and Nature of Dulness: Proper Nouns in The Dunciad,' Essays on Pope, ed. Pat Rogers (New York: Cambridge University Press, 1993), p. 98-128. For a discussion of the historical Theobald (as opposed to Pope's 'Tibbald'), see Peter Seary, Lewis Theobald and the Editing of Shakespeare (Oxford: Clarendon Press, 1990). 
the wrong reasons. Moreover, he is dead. Curiosity cabinets often featured items distanced in time and place, and The Dunciad likewise features numerous stock dunces from bygone ages. James McLaverty contends that ' $[t]$ he poet's interest is necessarily different from that of the....antiquarian, for he is looking for a tradition that will affirm and nurture his present practice. ${ }^{44}$ In The Dunciad, the poet affirms his present practice inversely through antiquarianism. Pope excavates such relics as Blome, Flecknoe, and Durfey, in order to demonstrate the continuity of dulness, and, in turn, to add historical weight to his argument. He therefore gives an ironic posterity to pedants, hacks, and fools, so that he may give legitimacy to his duncical cabinet. To adapt to The Dunciad the Preface' to Pope's 1717 edition of his Works: in this office of collecting my dunces, I am altogether uncertain, whether to look upon myself as a man building a monument, or burying the dead. ${ }^{45}$ As he damns to fame all his 'nameless names,' Pope may, in fact, look upon himself as both.

\section{Curious Posterity}

And, moreover, in damning to fame all his 'nameless names,' Pope establishes his own fame. The desired end of every collection is a kind of historical transcendence. Out of his Indian ladle, puffing Apples, and little box with the twelve Apostles in it, the curious collector attempts to build an edifice to his own achievements. 'The museum of the curious is a lasting monument,' remarks Dr. Fossile; and since this museum has been so closely identified with the collector, the monument is profoundly personal. ${ }^{46}$ The contents of the collection are immaterial to the existence of a collection, insofar as otherwise insignificant, irrelevant, and inconsequential curiosities have the potential to bring significance, relevance, and consequence to the collector himself. As Walter Houghton Jr. explains: 'Coins or pictures, shells or insects, none are valued for use, neither for the advancement of learning nor for immediate gain: they are

44 James McLaverty, 'Pope and Giles Jacob's "Lives of the Poets": The "Dunciad" as Alternative Literary History,' Modern Philology 83, no. 1 (August 1985): p. 25.

45 Adapted from The Prose Works of Alexander Pope, ed. Norman Ault (Oxford: Basil Blackwell, 1936), p. 295.

46 John Gay, Alexander Pope, and John Arbuthnot, Three Hours After Marriage, ed. John Harrington Smith (Los Angeles: William Andrews Clark Memorial Library, 1961), p. 189. 
valued in themselves...because their knowledge or collection guarantees a social reputation. ${ }^{47}$ And so too the cabinet of dulness contributes to Pope's reputation - both as a virtuoso and a satirist. The flyleaf to the first volume of the poet's self-assembled 'Library of Dunces,' bears a curious epigraph from Job 31.35:

Behold, it is my desire, that mine

Adversary had written a Book.

Surely I would take it on my

Shoulder, and bind it as a crown unto me. ${ }^{48}$

The epigraph might be said to epitomize Pope's 'poetics of collecting.' While The Dunciad compiles, classifies, and exhibits the dunces as mere curiosities, it simultaneously aggrandizes Pope as the maker of curiosities. 'Pope's verdict has been accepted,' observes James Sutherland, 'he has succeeded in imposing his own values on almost all of his dunces. ${ }^{49}$ Though much recent scholarship has demonstrated the limitations of Pope's evaluations, the necessary fact of their limitations reinforces the satiric usefulness of the collection. As Pope directs his patrons through the duncical cabinet, the quantitatively and the qualitatively small are brought into accord; the denizens of dulness are reduced to little more nor less than 'Petrified things' and 'Divers Figures cut on Shells'. And though Pope's parody of the collector's habit requires a paradoxical participation in the collector's habit, this participation makes for 'Congenial matter' indeed. Between butterflies and Breval, coins and Concanen, fungi and Foxton, Pope collects only to conquer.

DARRYL P. DOMINGO

University of Toronto

47 Houghton Jr., p. 56.

48 Cited in Mack, p. 235.

49 James Sutherland, 'Introduction' to The Dunciad, p. xlii. 


\section{Pope's 'Library of Dunces': or, Appendix}

Anonymous. Characters of the Times; Or, An Impartial Account of the Writings, Characters, Education, Ec. of several Noblemen and Gentlemen, libell'd in a Preface to a late Miscellany Published by P-PE and S-FT. London, 1728.

. A Compleat Collection of all the Verses, Essays, Letters and Advertisements, Which Have been occasioned by the Publication of Three Volumes of Miscellanies, by Pope and Company...With a large Dedication to the Author of the Dunciad, containing some Animadversions upon that Extraordinary Performance. London, 1728.

. An Essay on the Dunciad An Heroic Poem. London, 1728.

. Gulliver Decypher'd: or, Remarks On a late Book, intitled, Travels into Several Remote Nations of the World. London, n.d.

. A Letter from a Clergyman to his Friend, With an Account of the Travels of Capt. Lemuel Gulliver: And a Character of the Author. To which is added, the True Reasons why a certain Doctor was made a Dean. London, 1726.

[Breval, John Durant]. The Confederates: A Farce. By Mr. Gay. London, 1711.

Burnett, Thomas, and Duckett, George. Homerides: Or, a Letter to Mr. Pope, Occasion'd by his intended Translation of Homer. By Sir Iliad Doggrel. London, 1715.

[Concanen, Matthew]. A Supplement to the Profound. Containing Several Examples, very proper to Illustrate the Rules laid down in a late Treatise, called the Art of Sinking in Poetry.... London, 1728.

[Curll, Edmund]. The Curliad. A Hypercritic upon the Dunciad Variorum. With a Farther Key to the New Characters. London, 1729.

Dennis, John. Reflections Critical and Satyrical, upon a late Rhapsody, call'd An Essay Upon Criticism. London, n.d.

. A True Character of Mr. Pope and His Writings. London, 1716.

. Remarks Upon Mr. Pope's Translation of Homer. With Two Letters Concerning Windsor Forest, and the Temple of Fame. London, 1717.

. Remarks Upon Mr. Pope's Rape of the Lock. In Several Letters to a Friend. London, 1728.

. Remarks Upon Several Passages in the Preliminaries to the Dunciad, Both of the

Quarto and the Duodecimo Edition. And Upon Several Passages in Pope's Preface to his Translation of Homer's Iliad. London, 1729.

Drub, Timothy [pseud.]. A Letter to Mr. John Gay, Concerning His late Farce Entitled, A Comedy. London, 1717.

[Hill, Aaron]. The Progress of Wit: A Caveat. By Gamaliel Gunson, Professor of Physick and Astrology. London, 1730.

[Jacob, Giles]. The Mirrour: Or. Letters Satirical, Panegyrical, Serious and Humourous, on the Present Times...To wich is added A Legal Conviction of Mr. Alexander Pope of Dulness and Scandal, in the high Court of Parnassus. London, 1733.

[Oldmixon, John]. An Essay on Criticism; As it regards Design, Thought, and Expression, in Prose and Verse. By the Author of a Critical History of England. London, 1728. 
Parker, E. [pseud.]. A Compleat Key to the New Farce, call'd Three Hours After Marriage.

With an Account of the Authors. By E. Parker, Philomath. London, 1717.

Preston. [pseud.]. Aesop at the Bear-Garden: A Vision. By Mr. Preston. In Imitation of the Temple of Fame, a Vision, by Mr. Pope. London, 1715.

[Ralph, James]. Sawney. An Heroic Poem. Occasion'd by the Dunciad. Together with a Critique on that Poem ad-ressed to Mr. T-D,Mr.M-R, Mr. E-N, Ec.. London, 1728 .

[Roberts, John]. An Answer to Mr. Pope's Preface to Shakespeare. In a Letter to a Friend. Being a Vindication of the Old Actors who were the Publishers and Performers of that Author's Plays. London, 1729.

[Smedley, Jonathan]. Gulliveriana: Or, A Fourth Volume of Miscellanies. Being a Sequael of the Three Volumes, publish'd by Pope and Swift. To which is added, Alexandriana: or, A Comparison between the Ecclesiastical and Poetical Pope. London, 1728.

[Theobald, Lewis, and Griffin, Benjamin]. A Complete Key to the last New Farce The What $D^{\prime} Y e$ Call It. To Which is prefix'd a Hypercritical Preface on the Nature of Burlesque, and the Poets Design. London, 1715. 